\title{
ANALISIS KESALAHAN DALAM MENYELESAIKAN SOAL CERITA PADA MATA PELAJARAN MATEMATIKA SISWA KELAS V SDN 59 KOTA BENGKULU
}

\author{
Ansyori Gunawan \\ Pendidikan Guru Sekolah Dasar \\ Fakultas Keguruan dan Ilmu Pendidikan, Universitas Bengkulu
}

\begin{abstract}
Abstrak
Tujuan penelitian ini menggambarkan kesalahan dalam menyelesaikan soal cerita matematika. Jenis penelitian adalah deskriptif, subyek penelitian adalah siswa kelas $\mathrm{V}$ berjumlah 55. Teknik pengumpulan data berupa dokumentasi yang berhubungan dengan soal cerita yang telah dikerjakan siswa. Hasil penelitian berupa bentuk-bentuk kesalahan siswa yang terjadi pada setiap aspek yaitu: Pertama, adalah memahami soal yang yaitu menuliskan hal yang diketahui dan ditanyakan: (a) tidak menuliskan sama sekali, (b) tidak lengkap, (c) persis dengan soal, (d) menuliskan hal yang diketahui pada hal ditanyakan ataupun sebaliknya. Kedua, membuat model matematika yaitu: (a) tidak membuat model, (b) model tidak tepat. Ketiga, melakukan perhitungan yaitu: (a) tidak mengikuti prosedur, (b) perhitungan tidak tepat. Keempat, dalam menarik kesimpulan: (a) tidak sesuai dengan konteks jawaban, (b) tidak menuliskan sama sekali, (c) sama persis dengan pertanyaan. Selanjutnya kesalahan terbanyak yang terjadi yaitu: Pertama, aspek melakukan perhitungan, Kedua, membuat model matematika, Ketiga, memahami soal, dan Keempat, aspek menarik kesimpulan.
\end{abstract}

Kata Kunci: Analisis, Soal Cerita Matematika.

\section{PENDAHULUAN}

Sekolah dasar adalah pelaksana awal dalam pendidikan di Indonesia yang memerlukan perhatian serius dalam menanganinya karena pendidikan pada jenjang yang pertama ini merupakan pondasi bagi pendidikan di jenjang berikutnya. Pendidikan dasar memiliki peranan yang sangat penting, karena keberhasilan siswa dalam menguasai materi pelajaran di sekolah dasar dapat mempengaruhi keberhasilan pada jenjang pendidikan selanjutnya.

Matematika merupakan salah satu mata pelajaran yang diajarkan di sekolah dengan frekuensi jam pelajaran yang lebih banyak. Diharapkan dalam pembelajaran matematika, siswa mampu menguasai materi pelajaran sehingga siswa dapat menjelaskan dan memecahkan setiap permasalahan yang berhubungan dengan matematika secara cepat dan akurat, mengaplikasikan kemampuan yang telah dimiliki. Tujuan pembelajaran matematika di sekolah dasar yang terdapat dalam KTSP tahun 2006 yaitu agar siswa memahami konsep matematika, menjelaskan keterkaitan antar konsep dan mengaplikasikan konsep atau algoritma secara luwes, akurat, efesien dan tepat dalam pemecahan masalah dengan menggunakan kemampuannya yang meliputi kemapuan memahami masalah, merancang dan menyelesaikan model matematika serta menafsirkan solusi yang diperoleh.

Permendiknas RI nomor 22 tahun 2006 menyebutkan bahwa dalam pembelajaran matematika hendaknya dimulai dengan penggunaan masalah yang sesuai dengan situasi. Raharjo dkk. (2011:1) menyatakan bahwa dalam pembelajaran matematika hendaknya dibiasakan dengan mengajukan masalah yang nyata, masalah yang mengaitkan pembelajaran dengan kehidupan sehari-hari. pembelajaran yang memenuhi tuntutan tersebut adalah dengan pembelajaran pemecahan masalah.

National Council of Teacher Mathematics (NCTM) dalam Roebyanto dan Yanti (2007:4) memberikan beberapa rekomendasi dalam pembelajaran matematika salah satunya yang 
paling utama yaitu kurikulum dalam pembelajaran matematika harus berfokus pada penyelesaian masalah. Diperkuat oleh Raharjo dan Waluyati (2011:8) pentingnya kemampuan penyelesaian masalah pada pembelajaran matematika bahwa soal cerita yang erat kaitannya dengan kehidupan sehari-hari itu penting sekali diberikan dalam pembelajaran matematika di sekolah dasar karena pada umumnya soal cerita dapat digunakan untuk melatih siswa dalam menyelesaikan masalah.

Permasalahan yang sering terjadi banyak siswa yang kurang mampu dalam menguasai pelajaran matematika terutama yang berhubungan dengan soal cerita. Karena dalam menyelesaikan soal cerita tidak dapat dilakukan dengan satu langkah saja, tetapi siswa harus melalui beberapa tahapan yang membutuhkan pemahaman dan keterampilan yang baik dalam memahami soal, melakukan perhitungan dan ketrampilan menarik kesimpulan. Apabila siswa tidak menguasai salah satu tahap dalam menyelasikan soal cerita, maka siswa tersebut kesulitan bahkan gagal dalam menyelesaikan soal cerita matematika.

Berdasarkan observasi dan wawancara dengan siswa, mereka mengeluhkan kesulitan dalam menjawab soal cerita. Bahkan beberapa siswa mengeluhkan bahwa soal yang mereka kerjakan sangat berbeda dengan apa yang diajarkan guru. Menurut guru permasalahannya bukan pada soal yang tidak sama dengan apa yang diajarkan, tetapi karena sebagian besar siswa tidak memahami konsep dalam menyelesaikan soal cerita matematika. Siswa hanya terpaku dengan contoh soal yang diberikan, kebanyakan siswa menjawab dengan mengganti angka-angka yang ada pada soal dengan contoh jawaban yang diberikan oleh guru.

Pembelajaran merupakan suatu proses interaksi antara pendidik dan peserta didik dengan lingkungan, dimana pendidik menyampaikan bahan pelajaran secara terprogram agar siswa dapat belajar secara aktif untuk mencapai tujuan pembelajaran. Dimyati dan Midjiono (2009:297) menytatakan bahwa pembelajaran adalah kegiatan guru secara terprogram dalam desain intruksional untuk membuat siswa belajar aktif yang menekankan pada penyediaan sumber belajar. Selanjutnya Suryosubroto (2009:30) menambahkan bahwa yang dimaksud dengan pembelajaran adalah proses terjadinya interaksi guru dengan siswa dalam menyampaikan bahan pelajaran kepada siswa untuk mencapai tujuan pengajaran. Matematika merupakan bidang ilmu pengetahuan yang mempelajari tentang bilangan, hubungan antar bilangan serta prosedur yang digunakan dalam berhitung, mengukur, dan aljabar untuk mengembangakan kemampuan dan pemahaman dalam menyelesaikan masalah dilingkungan sekitar siswa yang berhubungan dengan bilangan. Hudoyo (2001:1) menyatakan bahwa belajar matematika berarti tentang konsepkonsep dan struktur matematika yang terdapat dalam materi yang dipelajari serta mencari hubungan konsep-konsep dan struktur matematika. Jadi pembelajaran matematika adalah proses komunikasi antara pendidik dan peserta didik dengan lingkungan, dimana pendidik secara terprogram mengkondisikan siswa agar dapat secara aktif mempelajari bilangan, hubungan antar bilangan serta makna dan konsep-konsep yang terdapat dalam matematika.

Salah satu kegiatan dalam pembelajaran matematika adalah menyelesaikan soal-soal matematika. Roebyanto dan Yanti (2007:15) mengelompokkan tugas (berupa soal) matematika atas dua macam yaitu soal pemecahan masalah (soal cerita) dan soal perhitungan rutin. Untuk $m$ ngukur kemampuan siswa dalam memahami konsep matematika biasanya menggunakan soal-soal yang berbentuk cerita maupun soal-soal matematika yang berbentuk noncerita. Seoal cerita matematika adalah soal yang berhubungan dengan kehidupan sehari-hari yang merupakan terapan dari suatu materi matematika. Raharjo dkk (2009:2) menyatakan soal cerita adalah soal yang disajikan dalam bentuk cerita pendek yang berupa masalah dalam kehidupan sehari-hari atau masalah lainnya yang dialami siswa yang dituliskan kedalam bentuk model matematika, 
dimana pemecahan masalahnya membutuhkan perhitungan dan konsep matematika.

Permasalahan dalam penelitian ini adalah:(a) Bagaimana bentuk kesalahan dalam menyelesaikan soal cerita matematika yang terjadi pada siswa kelas V SDN 59 Kota Bengkulu?(b) Aspek manakah kesalahan yang paling banyak terjadi pada siswa kelas V SDN 59 Kota Bengkulu dalam menyelesaikan soal cerita matematika? Atas dasar permasalahan tersebut tujuan penelitian iniadalah: (a) Mendeskripsikan bentuk kesalahan dalam menyelesaikan soal cerita matematika siswa kelas V SDN 59 Kota Bengkulu, (b) Mengetahui kesalahan yang paling banyak terjadi pada siswa kelas V SDN 59 Kota Bengkulu dalam menyelesaikan soal cerita matematika.

\section{METODE}

Dalam penelitian ini jenis penelitian yang digunakan adalah penelitian deskriptif. Penelitian deskriptif merupakan peneltian yang bertujuan untuk menggambarkan tentang suatu kejadian atau situasi tertentu pada populasi tertentu. Withney dalam Winarni (2011:12) menyatakan bahwa penelitian deskriptif adalah pencarian data mengenai interpretasi yang tepat untuk membuat gambaran mengenai situasi atau kejadian. Selanjutnya Sukmadinata (2011:72) menyatakan penelitian deskriptif adalah suatu bentuk penelitian yang paling dasar yang bertujuan untuk menggambarkan fenomena-fenomena ya ng ada.

Penelitian ini dilakukan di SDN 59 Kota Bengkulu. Subyek penelitian yang merupakan populasi dalam penelitian ini adalah seluruh siswa kelas $\mathrm{V}$ yang terdiri dari 2 kelas $\mathrm{A}$ dan $\mathrm{B}$ dengan jumlah 55 orang siswa terdiri dari 29 siswa laki-laki dan 26 siswa perempuan.

Data yang diperoleh berupa data kualitatif yang berupa kata-kata dan data kuantitatif yang berupa angka-angka. Data kualitatif yang digambarkan dengan kata-kata atau kalimat yang dipisah-pisah menurut katagori menurut katagori untuk memperoleh kesimpulan, sedangkan data kuantitatif adalah data yang berujud angka-angka hasil perhitungan atau pengukuran (Ismawati 2011:112).

Sumber data dalam penelitian ini adalah sumber data skunder yang didapat dari tangan kedua berupa dokumen-dokumen yang mendukung dalam pencarian data mengenai kesalahan siswa dalam menyelesaikan soal cerita matematika. Menurut Margono (2009:156) data skunder adalah data yang didapat dari tangan kedua seperti laporan, dokumen, nilai ujian dan lain-lain.

Teknik pengumpulan data yang digunakan adalah dokumentasi yaitu mengumpulkan data dengan mencatat data-data yang berupa tulisan maupun bukan tulisan yang telah ada. Menurut Sukmadinata (2011:221) dokumentasi adalah teknik pengumpulan data dengan menghimpun dan menganalisis dokumen-dokumen baik dokumen tertulis, gambar maupun elektronik. Lebih lanjut Riduwan (2011:77) menyatakan bahwa dokumentasi ditujukan untuk memperoleh data langsung dari tempat penelitian, meliputi buku-buku yang relevan, peraturan-peraturan, laporan kegiatan, foto-foto, film dan data yang relevan dengan penelitian.

Instrumen yang digunakan dalam penelitian ini adalah instrumen dokumentasi. Dokumen yang digunakan adalah semua arsip yang berupa lembar jawaban dalam menyelesaikan soal yang telah dikerjakan siswa mengenai soal cerita matematika. Dokumen ini kemudian diolah atau dianalisis dengan menggunakan checklist yang telah dipersiapkan.

Teknik analisis data yang digunakan dalam penelitian ini adalah teknik analisis statistik deskriptif yaitu menganalisis data dengan cara mendeskrisikan data yang telah terkumpul untuk memperoleh gambaran tentang kesalahan yang dilakukan siswa dalam menyelesaikan soal cerita matematika. Menurut Margono (2009:190) statistik deskriptif biasanya dipergunakan jika tujuan penelitiannya untuk penjajagan, tidak menarik kesimpulan, hanya menggambarkan tentang data yang ada.

Pada aspek kemampuan siswa dapat dihitung dengan menggunakan rumus dari Haryadi (2011:43) $P=\frac{F}{N} \times 100 \%$ 
Keterangan:

$\mathrm{P}=$ banyaknya persentase kesalahan pada aspek $\mathrm{X}$

$\mathrm{F}=$ jumlah skor jawaban salah pada aspek atau tiap aspek $\mathrm{X}$

$\mathrm{N}=$ jumlah sekor maksimal kesalahan jawaban siswa.

$\mathrm{X}$ adalah aspek: 1. Memahami soal, 2. Memahami model matematika, 3. Melakukan komputasi, 4. Menarik kesimpulan.

Adapun proses analisis terhadap lembar jawaban siswa adalah sebagai berikut:

1. Mengumpulkan data-data yang telah diperoleh.

2. Memeriksa langkah penyelesaian dan jawaban yang dilakukan siswa pada lembar jawaban.

3. Menghitung persentase siswa yang mengerjakan dan siswa yang melakukan kesalahan pada tiap butir soal.

4. Menyajikan data dalam bentuk tabel.

5. Mendeskripsikan data tiap butir soal yang dikelompokan berdasarkan aspek kesalahan yang telah ditetapkan dengan menyajikan variasi jawaban pada tiap butir soal. Kemudian dari variasi jawaban siswa dapat diketahui kesalahan-kesalahan yang terjadi dan banyaknya siswa yang melakukan kesalahan pada setiap aspek.

\section{HASIL}

Data-data dalam penelitian ini didapat dengan menggunakan instrumen dokumentasi. Dokumen yang diambil dari jawaban siswa dalam menyelesaikan soal-soal latihan, baik soal yang berasal dari buku paket maupun soal yang terdapat pada LKS yang digunakan siswa dalam kegiatan pembelajaran. jawaban siswa tersebut kemudian dianalisis dengan menggunakan daftar cek yang berisi aspek-aspek kesalahan yang diamati yaitu aspek memahami soal, membuat model matematika, melakukan perhitungan dan menarik kesimpulan.

Untuk menunjukkan kesalahan yang dialami siswa dalam menyelesaikan soal cerita matematika digunakan indikator tahapan dalam menyelesaikan soal cerita matematika yaitu Pertama, siswa dikatakan tidak dapat memahami soal $\left(\mathrm{X}_{1}\right)$ apabila siswa tidak lengkap dalam menuliskan apa yang diketahui (A) dan apa yang ditanyakan dalam soal (B), Kedua, siswa dikatakan salah dalam membuat model matematika $\left(\mathrm{X}_{2}\right)$ apabila siswa tidak dapat mengubah soal cerita matematika kedalam kalimat matematika, Ketiga, siswa dikatakan tidak dapat melakukan perhitungan $\left(\mathrm{X}_{3}\right)$ apabila siswa dapat menyelesaikan model dengan operasi perhitungan yang telah ditentukan (A) dan tidak dapat melakukan perhitungan memperoleh hasil perhitungan yang tepat, Keempat, siswa dikatakan salah dalam menarik kesimpulan $\left(\mathrm{X}_{4}\right)$ apabila siswa tidak dapat menuliskan jawaban ke dalam bentuk teks yang sesuai konteks jawaban yang dimaksud oleh soal.

1. Perhitungan kesalahan tiap tahap pada tiap aspek penyelesaian soal cerita.

Hasil analisis didapat skor dari semua siswa yang berjumlah 55 orang siswa yang salah dalam menyelesaikan soal cerita matematika pada tiap butir soal. Dengan demikian a) skor maksimal kesalahan jawaban siswa pada setiap masing-masing soal adalag 55 . Skor maksimum yang digunakan pada perhitungan prosentaase kesalahan siswa pada tiap item soal adalah 55. b) Skor maksimal kemungkinan terjadi kesalahan siswa pada semua butir soal (butir soal ada 7 ) adalah sebanyak $55 \times 7=385$. Dengan demikian, skor maksimum dalam menghitung persentase kesalahan siswa pada seluruh item soal adalah 385 . 
Tabel 1. Skor hasil analisis jawaban siswa pada tiap tahap penyelesaian soal cerita matematika pada semua item.

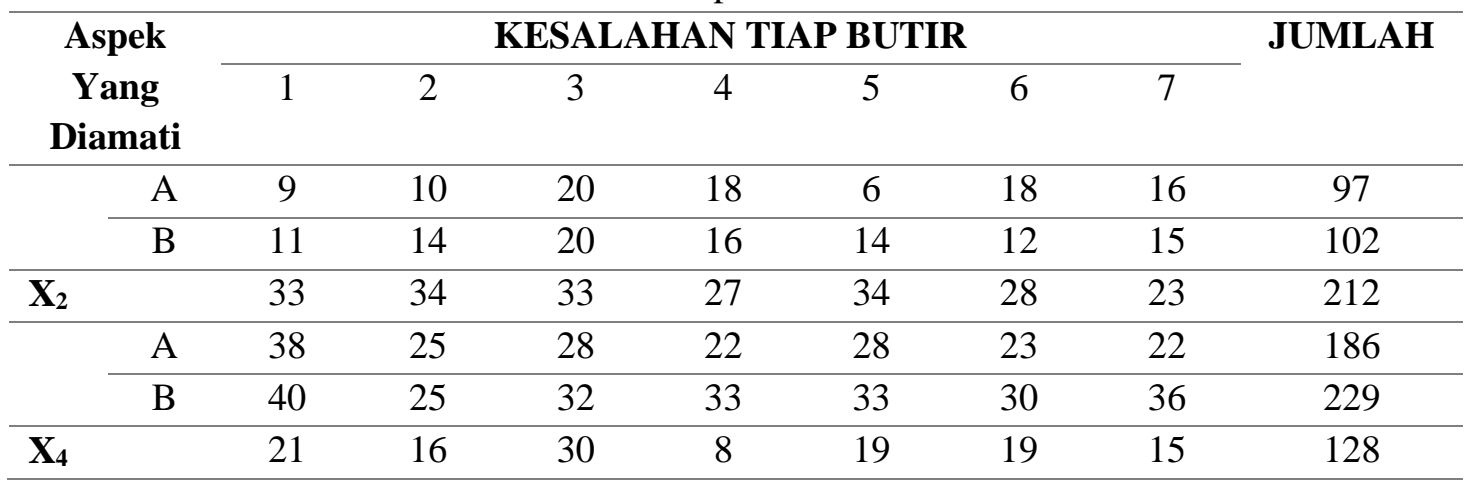

Keterangan:

$\mathrm{X}_{1} \quad$ : Kesalahan memahami soal

$\mathrm{X}_{2} \quad$ : Kesalahan membuat model matematika

$\mathrm{X}_{3} \quad$ : Kesalahan dalam melakukan perhitungan

$\mathrm{X}_{4} \quad$ : Kesalahan dalam menarik kesimpulan

A : Tahap A

B : Tahap B

Tabel 2.Perolehan skor kesalahan siswa dalam menyelesaikan soal cerita matematika ditinjau dari tiap aspek X.

\begin{tabular}{ccccccccccc}
\hline No. & $\begin{array}{c}\text { ASPEK } \\
\text { YANG }\end{array}$ & \multicolumn{8}{c}{ KESALAHAN SISWA TIAP BUTIR SOAL } & \multirow{2}{*}{ JUMLAH } \\
\cline { 3 - 8 } & DIAMATI & & 2 & 3 & 4 & 5 & 6 & 7 & \\
\hline $\mathbf{1}$ & $\mathrm{X}_{1}$ & 15 & 15 & 25 & 22 & 16 & 22 & 21 & 136 \\
\hline $\mathbf{2}$ & $\mathrm{X}_{2}$ & 33 & 34 & 33 & 27 & 34 & 28 & 23 & 212 \\
\hline $\mathbf{3}$ & $\mathrm{X}_{3}$ & 41 & 26 & 35 & 35 & 37 & 35 & 39 & 248 \\
\hline $\mathbf{4}$ & $\mathrm{X}_{4}$ & 21 & 16 & 30 & 8 & 19 & 19 & 15 & 128 \\
\hline
\end{tabular}

2. Kesalahan siswa dalam menyelesaikan soal cerita pada tiap aspek $X$

Atas dasar tabel 1 dan tabel 2, kemudian dilakukan perhitungan persentase kesalahan siswa dalam menyelesaikan soal cerita matematika pada tiap aspek $\mathrm{x}$ dengan menggunakan rumus $P=\frac{F}{N} \times 100 \%$.

a. Pada aspek memahami soal.

Langkah yang harus ditempuh siswa dalam menyelesaikan soal cerita matematika adalah dengan menuliskan hal yang diketahui dan hal yang ditanyakan dalam soal. Setelah dilakukan perhitungan, didapat data kesalahan yang terjadi pada aspek $\mathrm{X}_{1}$ Atas daasar hasil analisis pada item nomor 1 sebanyak 15 siswa $(21,8 \%)$ melakukan kesalahan dalam memahami soal dengan rincian 9 siswa $(16,4 \%)$ salah dalam menulis hal yang diketahui dalam soal, dan 11 siswa (20\%) melakukan kesalahan dalam menuliskan hal yang ditanyakan dalam soal.

Pada item soal nomor 2 sebanyak 15 siswa $(21,8 \%)$ yang mengalami kesalahan dalam memahami soal. Pada langkah-langkah memahami soal 10 siswa $(18,1 \%)$ yang melakukan kesalahan dalam menuliskan kembali hal yang diketahui dalam soal dan sebanyak 14 siswa $(25,5 \%)$ yang melakukan kesalahan dalam menuliskan kembali hal yang ditanyakan dalam soal.

Pada item soal nomor 3, sebanyak 25 siswa yang mengalami 
kesulitan dalam memahami soal dengan rincian masing-masing sebanyak 20 siswa $(30,2 \%)$ yang salah dalam menuliskan hal yang diketahui dan hal yang ditanyakan dalam soal.

Pada soal nomor 4, terdapat 22 siswa (40\%) yang melakukan kesalahan dalam memhami soal cerita matematika. Dengan rincian siswa yang melakukan kesalahan dalam menyelesaikan soal cerita matematika dari 22 orang siswa tersebut adalah sebanyak 18 orang siswa $(32,7 \%)$ yang salah dalam menuliskan hal yang diketahui dalam soal, dan 16 orang siswa $(29,1 \%)$ yang salah dalam menuliskan hal yang ditanyakan dalam soal.

Pada item soal nomor 5, diketahui terdapat 16 siswa $(29,1 \%)$ yang dikatagorikan salah dalam memahami soal. Sebanyak 6 siswa $(10,9 \%)$ tidak lengkap menuliskan kembali hal yang diketahui dalam soal. Sebanyak 14 siswa $(25,5 \%)$ melakukan kesalahan dalam menuliskan hal yang ditanyakan dalam soal.

Pada item soal nomor 6 sebanyak 22 siswa (40\%) yang salah dalam memahami soal. Sebanyak 18 siswa $(33,7 \%)$ tidak dapat menuliskan hal yang diketahui dalam soal dan sebanyak 12 siswa $(21,9 \%)$ yang tidak dapat menuliskan hal yang ditanyakan dalam soal.

Pada butir soal nomor 7, terdapat 21 siswa $(38,2 \%)$ yang dikatagorikan kedalam siswa yang tidak dapat memahami soal dengan rincian masingmasing sebanyak 16 siswa $(29,1 \%)$ dan 15 siswa (27,3\%) yang salah dalam menuliskan yang diketahui dan yang ditanyakan dalam soal.

Secara keseluruhan, persentase kesalahan siswa dalam menyelesaikan soal cerita matematika ditinjau dari aspek $\mathrm{X}_{1}$ dapat dilihat pada tabel.
TABEL 3. Persentase total skor kesalahan siswa dalam menyelesaikan soal cerita matematika pada tahap aspek $\mathrm{X}_{1}$.

\begin{tabular}{|c|c|c|c|c|c|}
\hline \multirow{2}{*}{\multicolumn{2}{|c|}{$\begin{array}{c}\text { KESALAHAN } \\
\text { SISWA TIAP } \\
\text { ASPEK } X_{1}\end{array}$}} & \multicolumn{4}{|c|}{$\begin{array}{c}\text { KESALAHAN PADA } \\
\text { TIAP LANGKAH }\end{array}$} \\
\hline & & \multicolumn{2}{|c|}{ A } & \multicolumn{2}{|c|}{ B } \\
\hline $\mathbf{F}$ & $\%$ & $\mathrm{~F}$ & $\%$ & $\mathrm{~F}$ & $\%$ \\
\hline 136 & 35,3 & 97 & 25,2 & 102 & 26,5 \\
\hline \multicolumn{6}{|c|}{ Keterangan: } \\
\hline \multicolumn{4}{|c|}{$\begin{aligned} \text { A : } & \text { Tahap menuliskan } \\
& \text { diketahui }\end{aligned}$} & hal & yang \\
\hline B & $\begin{array}{r}\text { Tah } \\
\text { ditar }\end{array}$ & & uliska & hal & \\
\hline $\mathrm{F}$ & : Freku & asi k & lahan & & \\
\hline$\%$ & : per & & & & \\
\hline
\end{tabular}

\section{b. Pada Aspek Membuat Model} Matematika.

Skor dan persentase kesalahan yang terjadi pada aspek membuat model matematika dapat disajikan pada tabel.

TABEL 4. Persentase skor kesalahan siswa dalam menyelesaikan soal cerita matematika pada aspek $\mathrm{X}_{2}$.

\begin{tabular}{|c|c|}
\hline \multirow[t]{2}{*}{$\begin{array}{c}\text { Nomor Item } \\
\text { Soal }\end{array}$} & $\begin{array}{c}\text { Kesalahan Siswa } \\
\text { Tiap Aspek X2 }\end{array}$ \\
\hline & $\%$ \\
\hline 1 & 60 \\
\hline 2 & 61,8 \\
\hline 3 & 33 \\
\hline 4 & 49,1 \\
\hline 5 & 61,8 \\
\hline 6 & 50,9 \\
\hline 7 & 41,8 \\
\hline JUMLAH & 212 \\
\hline $\begin{array}{l}\text { Jumlah } \\
\text { mor } 1 \text { sampai } \\
\text { embuat model } \\
\text { 12. Skor mak } \\
\text { enyelesaikan } \\
\text { hingga perse } \\
\text { elakukan kesa }\end{array}$ & $\begin{array}{l}\text { nua skor item soal } \\
\text { omor } 7 \text { pada aspek } \\
\text { matematika sebesar } \\
\text { mum siswa dalam } \\
\text { l cerita yaitu } 385 \\
\text { ase siswa yang } \\
\text { lan pada aspek } \mathrm{X}_{2}\end{array}$ \\
\hline
\end{tabular}

c. Pada Aspek Melakukan Perhitungan.

Kesalahan terjadi pada aspek melakukan perhitungan meliputi kesalahan dalam menyelesaikan model dengan operasi yang telah ditentukan 
dan kesalahan dalam memperoleh hasil perhitungan. Pada item soal nomor 1 terdapat 41 siswa $(74,5 \%)$ yang melakukan kesalahan dalam melakukan perhitungan dengan rincian sebanyak 38 siswa $(69,1) \quad$ kesalahan dalam menyelesaikan model dan 40 siswa $(72,7 \%)$ melakukan kesalahan dalam memperoleh perhitungan yang tepat.

Kesalahan dalam perhitungan pada item soal nomor 2 terjadi pada 26 siswa $(47,3 \%)$. Banyaknya siswa yang salah dalam menyelesaikan model dan memperoleh hasil perhitungan sebanyak 25 siswa $(45,5 \%)$. Kesalahan dalam perhitungan pada item soal nomor 3 terjadi pada 35 siswa $(63,6 \%)$. Siswa yang salah dalam menyelesaikan model matematika terdapat sebanyak 28 siswa $(50,9 \%)$ sedangakan siswa yang salah dalam memperoleh hasil perhitungan terdapat 32 siswa $(58,2)$.

Kesalahan dalam melakukan perhitungan pada item soal nomor 4 sebanyak 35 siswa $(63,6 \%)$. Siswa yang tidak dapat menyelesaikan model matematika dengan menggunakan operasi yang telah ditentukan sebanyak 22 siswa (40\%), sedangkan yang melakukan kesalahan dalam mendapatkan hasil perhitungan sebanyak 33 siswa (60\%). Pada item soal nomor 5 terdapat 37 siswa $(67,3 \%)$ yang salah dalam mengenrjakan operasi perhitungan. Sebanyak 28 siswa $(50,9 \%)$ melakukan kesalahan dalam menyelesaikan model dan 33 siswa (60\%) yang terdapat kesalahan tidak tepat dalam memperoleh hasil perhitungan.

Siswa yang melakukan kesalahan dalam melakukan perhitungan pada item soal nomor 6 sebanyak 35 siswa $(63,6 \%)$. Siswa yang tidak dapat menyelesaikan model matematika dengan men ggunakan operasi yang telah ditentukan sebanyak 23 siswa $(41,5 \%)$, sedangkan siswa yang melakukan kesalahan dalam mendapatkan hasil perhitungan sebanyak 30 siswa (54,5\%). Pada item soal nomor 7 terdapat 39 siswa $(70,9 \%)$ melakukan kesalahan pada aspek melakukan perhitungan. Kesalahan siswa dalam menyelesaikan model yang telah ditentukan sebanyak 22 siswa (40\%), sedangkan siswa yang salah dalam mendapatkan hasil perhitungan sebanyak 36 siswa $(65,5 \%)$.

TABEL 5. Persentase total skor kesalahan siswa dalam menyelesaikan

soal cerita matematika pada tahap aspek $\mathrm{X}_{3}$

\begin{tabular}{cccccc}
\hline \multirow{2}{*}{$\begin{array}{c}\text { Kesalahan } \\
\text { Siswa Tiap } \\
\text { Aspek } X_{3}\end{array}$} & \multicolumn{4}{c}{$\begin{array}{c}\text { Kesalahan Pada Tiap } \\
\text { Langkah }\end{array}$} \\
\cline { 3 - 6 } \multicolumn{2}{c}{$\%$} & \multicolumn{2}{c}{ A } & \multicolumn{2}{c}{ B } \\
\hline F & $\%$ & F & $\%$ & F & 5 \\
\hline $\mathbf{2 4 8}$ & 64,4 & 186 & 48,4 & 229 & 59,5 \\
\hline
\end{tabular}

\section{d. Pada Aspek Menarik Kesimpulan.}

Aspek yang terakhir dalam menyelesaikan soal cerita matematika adalah menarik kesimpulan dari soal dan perhitungan yang telah dilakukan. Berdasarkan data yang diperoleh, terdapat kesalahan dalam menarik kesimpulan pada item soal nomor 1 yang dilakukan oleh sebanyak 21 siswa $(38,2 \%)$. Pada item soal nomor 2, diketahui sebanyak $16(29,1 \%)$ siswa melakukan kesalahan. Pada item soal nomor 3 terdapat 30 siswa $(54,5 \%)$ yang melakukan kesalahan.

Selanjutnya pada item soal nomor 4, siswa yang salah dalam menyimpulkan sebanyak 8 orang siswa $(14,5 \%)$. Pada soal nomor 5 dan 6, terdapat 19 siswa $(34,5 \%)$ yang melakukan kesalahan. Seda ngkan pada item soal nomor 7 terdapat 15 siswa $(27,2 \%)$ yang salah dalam menyimpulkan hasil jawaban.

Skor total yang diperoleh pada tahap $\mathrm{X}_{4}$ sebesar 128 dari skor 
maksimal pada tiap tahap 385 sehingga diperoleh persentase kesalahan siswa pada tahap menarik kesimpulan $33,2 \%$. Dengan demikian kesalahan yang paling banyak terjadi pada siswa pada aspek $\mathrm{X}_{3}$ kesalahan dalam melakukan perhitungan, sedangkan $\mathrm{X}_{2}$ menempati urutan kedua. Kesalahan terbanyak ketiga pada aspek $X_{1}$, sedangkan $X_{4}$ merupakan aspek kesalahan yang paling sedikit terjadi.

\section{PEMBAHASAN}

Kesalahan yang dilakukan siswa dapat dilihat dari empat aspek kesalahan yang diteliti yaitu: Pertama, aspek memahami soal menuliskan hal yang diketahui dan ditanyakan dalam soal. Kedua, kesalahan dalam menerjemahkan soal kedalam model matematika. Ketiga, aspek melakukan perhitungan yang harus sesuai prosedur dan mendapatkan hasil yang tepat. Keempat, aspek menarik kesimpulan, menuliskan kembali hasil jawaban kedalam bentuk teks, Ahmad dalam Raharjo dkk (2009:14).

Hasil analisis lembar jawaban siswa dalam menyelesaikan soal cerita matematika bahwa kemampuan siswa dalam menyelesaikan soal cerita masih tergolong rendah. Kesalahan terbanyak yang dilakukan siswa pada aspek melakukan perhitungan. Berikutnya kesalahan kedua dalam membuat model matematika. Urutan kesalahan terbanyak ketiga kesalahan dalam memahami soal. Kesalahan yang paling sedikit terjadi pada aspek memahami soal.

1. Kesalahan Penyelesaian Aspek $X_{1}$.

Pada aspek $\mathrm{X}_{1}$ atau aspek kesalahan dalam memahami soal seperti yang telah dijabarkan sebelumnya, kesalahan pada aspek ini merupakan kesalahan yang menempati urutan ketiga kesalahan terbanyak. Pada aspek $\mathrm{X}_{1}$ ini terjadi 102 kesalahan dari sejumlah skor maksimum kemungkinan terjadi kesalahan dengan persentase sebesar 35,7\%. Kesalahan aspek ini meliputi kesalahan dalam memahami hal yang diketahui dalam soal yang terjadi sebanyak 97 kesalahan $(25,2 \%)$ dan kesalahan dalam memahami hal ditanyakan dalam soal terjadi sebanyak 102 $(26,5 \%)$. Secara umum, siswa dianggap melakukan kesalahan karena (a) siswa tidak lengkap dalam menuliskan hal yang diketahui dan hal yang ditanyakan dalam soal; (b) siswa menuliskan hal yang diketahui sama persis dengan teks soal; (c) siswa menuliskan hal yang diketahui pada hal yang ditanyakan; (d) siswa menuliskan hal yang diketahui pada hal yang ditanyakan atau sebaliknya; (e) siswa tidak menuliskan hal yang diketahui atau hal yang ditanyakan sama sekali.

2. Kesalahan Penyelesaian Aspek $X_{2}$.

Kesalahan pada sapek $\mathrm{X}_{2}$ yaitu kesalahan dalam mengubah soal cerita kedalam bentuk model matematika. Aspek ini menempati urutan kesalahan terbanyak kedua. Terjadi sebanyak 212 keslahan $(55,1 \%)$ kesalahan dari sekor maksimum kemungkinan keslahan yang dapat terjadi. Berdasarkan analisis yang telah dilakukan, kesalahan yang terjadi karena kebanyakan siswa tidak memahami unsurunsur yang terdapat dalam soal. Kata kunci yang dimaksudkan adalah kata kunci seperti yang dijelaskan oleh Raharjo (2008:8) bahasa matematika dalam soal cerita matematika, misalkan pada soal cerita terdapat kata-kata "diberikan" atau "hil;ang" merupakan katakata yang merujuk pada pengurangan, sedangkan kata-kata "diberikan" atau "mendapat" merupakan kata-kata yang merujuk pada penjumlahan. Banyak siswa yang tidak mengetahui kata kunci tersebut mengakibatkan banyaknya siswa yang mengerjakan dengan menggunakan operasi penjumlahan tidak sesuai ketentuan.

3. Kesalahan Penyelesaian Aspek $X_{3}$.

Kesalahan penyelesaian soal cerita pada aspek $\mathrm{X}_{3}$ merupakan kesalahan terbanyak yang terjadi pada siswa dalam menyelesaikan soal cerita matematika. Kesalahan dalam hal melakukan operasi perhitungan dengan jumlah kesalahan yang terjadi sebanyak 248 kesalahan $(64,4 \%)$ dari 385 kemungkinan kesalahan yang terjadi. Kesalahan ini terjadi karena siswa kurang menguasai konsep perhitungan hingga akhirnya pada aspek $\mathrm{X}_{3}$ 
tahap A terjadi 229 kesalahan $(59,5 \%)$ dan pada tahap B terdapat $128(33,2 \%)$ kesalahan. Hal ini terlihat pada beberapa siswa yang dapat menuliskan model matematika dengan benar tetapi tidak dapat menyelesaikan model tersebut hingga akhirnya sebagian siswa belum dapat menemukan hasil perhitungan yang benar.

4. Kesalahan Penyelesaian Aspek $X_{4}$.

Kesalahan pada aspek $\mathrm{X}_{4}$ yaitu kesalahan dalam menarik kesimpulan merupakan kesalahan siswa yang paling sedikit terdapat $128(33,2 \%)$ kesalahan siswa dalam menarik kesimpulan. Pada tahap ini, siswa dikatakan salah apabila siswa tidak dapat menuliskan kembali jawaban kedalam teks sesuai dengan konteks soal. Pada tahap ini, siswa dianggap tidak dapat menuliskankdesalahan karena (a) siswa tidak menuiskan kesimpulan jawaban sama sekali; (b) kesimpulan yang dibuat siswa tidak sesuai dengan konteks soal; (c) menuliskan kesimpulan persis dengan pertanyaan soal.

Kesalahan lain adalah siswa tidak menuliskan kesimpulan jawaban sama sekali. Kemungkinan penyebab siswa tidak menuliskan kesimpulan jawabankarena lupa dalam menuliskan kesimpulan, artinya siswa tidak cermat dalam menyelesaikan soal cerita matematika. Atau siswahanya menuliskan hal yang ditanyakan dalam soal kemudian ditambah dengan hasil akhir perhitungan tanpa memahami kesimpulan dari jawaban yang didapatkan dari penyelesaian soal cerita matematika.

\section{SIMPULAN}

Berdasarkan hasil penelitian dan pembahasan kesalahan dalam menyelesaikan soal cerita matematika yang dilakukan siswa kelas V SDN 59 Kota Bengkulu, dapat disimpulkan sebagai berikut ini:

1. Kesalahan siswa dalam menyelesaikan soal cerita matematika ditunjukkan dengan kesalahan dalam menuliskan langkah-langkah penyelesaian soal cerita yang telah dikerjakan siswa yaitu: a. Kesalahan dalam memahami soal.

Kesalahan siswa dalam memahami soal terjadi sebanyak 136 kesalahan $(35,3 \%)$. Kesalahan siswa pada aspek ini meliputi kesalahan dalam menuliskan hal yang diketahui dan ditanyakan dalam soal dengan banyaknya kesalahan yang terjadi masing-masing sebesar 97 kesalahan $(25,2 \%)$ dan 102 kesalahan $(26,5 \%)$. Bentuk kesalahan siswa dalam menyelesaikan soal cerita pada aspek ini (a) siswa tidak menuliskan hal yang diketahui ataupun hal yang ditanyakan; (b) siswa tidak lengkap menuliskan hal yang diketahui dan yang ditanyakan; (c) menuliskan hal yang diketahui dan hal yang ditanyakan sama persis dengan teks soal; (d) siswa menuliskan hal yang diketahui pada hal yang ditanyakan atau sebaliknya.

b. Kesalahan dalam membuat model.

Pada aspek ini kesalahan terjaqdi karena siswa kurang memahami kata kunci dalam soal cerita yang merujuk pada operasi penjumlahan, pengurangan, perkalian dan pembagian. Kurangnya pemahaman siswa mengenai kata kunci tersebut mengakibatkan terjadinya kesalahan sebanyak 212 kesalahan (55,1\%). Bentuk kesalahan siswa pada aspek ini yang pertama siswa tidak membuat model matematika; kedua, tidak tepat dalam membuat model matematika.

c. Kesalahan dalam melakukan perhitungan. Kesalahan dalam melakukan perhitungan meliputi kesalahan dalam menyelesaikan model dan memperoleh hasil perhitungan yang tepat. Bentuk kesalahan siswa pada tahap melakukan perhitungan pertama, siswa tidak mengikuti prosedur dalam menyelesaikan model yang telah dibuat; kedua, siswa mengikuti prosedur dalam menyelesaikan model, tetapi salah dalam melakukan perhitungan. Pada aspek ini terjadi sebanyak 186 kesalahan $(48,4 \%)$ dalam menyelasikan model, sedangkan kesalahan dalam memperoleh hasil 
perhitungan yang terjadi sebanyak 229 kesalahan $(59,5 \%)$.

d. Kesalahan dalam menarik kesimpulan.

Kesalahan pada aspek menarik kesimpulan terjadi sebanyak 128 kesalahan $(33,2)$. Pada aspek ini bentuk kesalahan yang terjadi, pertama, menuliskan kesimpulan jawaban tidak sesuai dengan konteks yang diharapkan soal; kedua, siswa yang tidak menuliskan kesimpulan jawaban sama sekali; ketiga, menuliskan kesimpulan sama persis pertanyaan soal.

2. Kesalahan yang paling banyak dilakukan oleh siswa adalah kesalahan dalam melakukan perhitungan $(64,4 \%)$. Kesalahan terbanyak kedua terjadi pada aspek membuat model matematika $(55,1 \%)$. Kesalahan terbanyak selanjutnya kesalahan pada aspek memahami soal (35,3\%). Kesalahan yang paling sedikit terjadi adalah kesalahan pada aspek menarik kesimpulan $(33,2 \%)$.

\section{SARAN}

Berdasarkan penelitian yang telah dibahas dan disimpulkan, banyaknya kesalahan yang terjadi pada siswa dalam menyelesaikan soal cerita matematika, maka disarankan:

1. Bagi guru, hendaknya lebih banyak memberi latihan, pemahaman dan bimbingan mengenai penyelesaian soal cerita matematika siswa menjadi terbiasa dan mampu menguasai permasalahan yang dekat dengan kehidupan siswa. Dalam pembelajaran, guru lebih menekankan konsep-konsep dasar matematika terutama dalam melakukan operasi perhitungan. Guru perlu memberikan pemahaman tentang "kata kunci" yang tepat dalam menyelesaikan soal cerita matematika.

2. Bagi peneliti lain dapat meneliti lebih lanjut mengenai kesulitan siswa dalam menyelesaikan soal cerita matematika terutama faktor yang mempegaruhi terjadinya kesulitan yang menimbulkan banyak keslahan yang terjadi pada siswa dalam menyelesaikan soal cerita matematika.

\section{DAFTAR PUSTAKA}

Dimyati, Mudjiono. 2009.Belajar dan Pembelajaran, Jakarta: Rineka Cipta.

Haryadi, Moh. 2011.Statistik Pendidikan. Jakarta: Prestasi Pustaka Publisher.

Hudoyo, Herman dkk.2001.Matematika. Jakarta: Depdikbud,Dikti, BPPPGSD.

Ismawati, Esti. 2011.Metode Penelitian Pendidikan Bahasa dan Sastra. Surakarta: Yuma Pustaka.

Margono, S. 2009.Metode Penelitian Pendidikan. Jakarta: Rineka Cipta.

Raharjo, Marsudi; dkk. 2008.Pembelajaran Soal Cerita Yang Berhubungaqn Dengan Penjumlahan dan Pengurangan di SD. Yogyakarta: PPPPTK Matematika.

2009.Pembelajaran soal Cerita di SD. Yogyakarta: PPPPTK Matematika.

---------. 2011.Pembelajaran Soal Cerita Operasi Hitung Campuran di SD. Yogyakarta: PPPPTK Matematika.

Roebyanto, Gunawan; Yanti, Aning Wida. 2007.Modul Pemecahan masalah Matematika, http://jijgsd.com/search/pemecahan masalah matematika. diakses 12 - 07 2012.

Sukmadinata, Nana Syaodih. 2011.Metode Penelitian Pendidikan. Bandung: Rosdakarya.

Suryosubroto, B. 2009.Proses Belajar Mengajar di Sekolah. Jakarta: Rineka Cipta.

Winarni, Endang Widi. 2011.Penelitian Pendidikan. Bengkulu: FKIP Unib. 